\author{
目次 \\ Jax Lab 情報 \\ Jackson 研究所留学メモ：児島昭徳 \\ (愛知県かんセンター研究所病理学第二部)
}

\title{
Jackson 研究所留学メモ
}

児島昭德（愛知県がんセンター研究所病理学第二部）

去年の暮れから今年にかけて，センセーショナルな記 事に付随して The Jackson Laboratory の名が日本 の新聞に 2 回載った。一回は George D. Snell への) 一ベル医学生理学賞授与, む5一回は Peter C. Hoppe の Karl Illmensee との共同研究, クローンマウスの 作出に関する記事である。一方，この 4 月には前所長の R. T. Prehn がカルフォルニア, San Jose の The Institute for Medical Research に移り, 新所長に は, Harvard, Sidney Farber Cancer Institute の Barbara H. Sanford が内定し， 7 月以後着任すると いら。去年 9 月に留学を終えて州国してからでもこのよ 5 K Jackson 研究所 (以後 Jax Lab と称す) をとり まく情勢は大きく変りつつあり, 私の 2 年間の経験もど んどん色あせたものになってゆくものと思われる。従っ て, 留学中, 疾患モデル動物ニュースの編集部より依頼 を受けてそのままになっていた留学先からの報告を、こ の際 Jax Lab の印象記のような形で読者の参考のため 報告しておきたいと思ら。その時々の Jax Lab に関す る情報は，本ニュースに周到な報告が続いているので， 私は自分の経験のなかで日本の噈者に比較的耳新しいの ではと思われる事柄に的をしぼりたい。

1） Jackson 研究所及び Jax マウスの值らち

Jax Lab は世界最大の mammarian genetics の 研究所と名乗っているが, その実, 有数の癌研究所でも ある。私が留学先にここを選んだのも，UICC（国際対 癌連合) 主催の癌研究の Training Course が1979年
ここで開かれたのもその理由による。一つには, 研究費 の多くを癌研究に関連づけて得ている現実がありいま一 つには, 創設者 C. C. Little が, 小さい頃から fancy マウスに慣れ親しみ，ある系統 (毛色) のマウスにしば しば癌が自然発生することを大学で経験するなかで, 癌 研究を最大の関心事としたといら歴史的背景がある。癌 を遺伝学の立場から攻めよらとして, 手段としての inbred マウスの可能性之有用性に注目したのである。対 照的に, 山極, 市川のウサギにおける実験的タール癌の 成功が，さらに容易に実験虎を入手するために発癌剂, 発癌方法の改良, さらには現在の環境発癌物質の検索へ と進展した日本の癌研究の歴史を考学ると興味深い。従 って，Jax Labを実験動物としての質の良いマウスあ るいはラビットを育成，供給する機関だぐらいにとらえ ていては非常に大切な点を見落す。この考えは, ややも すれば日本に種マウスを導入しさえすれば Jax Labに 相当するものが作れるといら安易な発想につながる。 Jax マウスのファンが世界中にいるのは, 世界に先がけ てマウスを供給してきたからでも, 単に細菌学的, 遗伝 学的にきれいなマウスを供給してくれるからでもなく, Jax Lab の個々の研究者が inbred マウスの特性を熟 知し，使いこなし，その価値を引き出してきたからにほ かならない。即ち, Jax Lab のそして Jax マウスの 值らちは, それが歴代有してきた staff の質の重みであ る。もし, 実験動物を自在に使いこなせる優れた研究者 を置かずに, 動物供給センターとして管理, 運用するな 
ら，その生産するマウスはすぐにも魅力を失らであろ ら。事実, 世界に供給される Jax マウスは, 常に同世 代のマウスを Jax Lab の staff が自分の独創的な研 究に使用し魅力を保つよう配慮されている。まさに, 研 究者あってのマウスである。

2） Jax マウスに関するトピックス

a) $\mathrm{AKR} / \mathrm{J}-n u^{s t r} / n u^{s t r}$

$\mathrm{AKR} / \mathrm{J}$ という inbred strain に自然におこった， $n u$ 遺伝子座の mutation で nude と区別して streaker

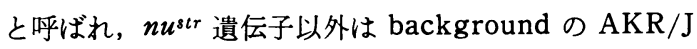
と全く同じで, nude gene に関する現在唯一の coisogenic strain である。NIH の援助により E.M. Eicher が維持しており，株の分与もなされているが，従来の congenic タイプの nude マウスに比べ繁殖能はあまり 良くないよらである。我が国では川崎の実験動物中央研 究所に導入, 維持されているが, やはり生産は低いと聞 いている。SPF で飼らだけでは繁殖率が良くならない となると, AKR/J の background が streaker の生 殖能力に何らかの影響を与えているのかもしれない。現 在私も, 以前 conventional ヌードマウスの繁殖能力を 改善させた方法を用いて念のため streaker マウスの能 力を上げるべく検討中である。

b) $\mathrm{MRL} / \mathrm{Mp}-l p r / l p r$ 及び BXSB/Mp

前者は E. D. Murphy (M) と彼の senior assistant の J. B. Roth (R) が育てあげた lymphoproliferation （L）を特徵とする自己免疫病自然発症マウスで， $1 \mathrm{ym}$ phoproliferation の症状は $l p r$ といら劣性遺伝子のせ いだといらことが分り, 現在いくつかの既存の inbred マウスにこの gene が移入されつつある。従って将来, $\mathrm{MRL} / \mathrm{Mp}$ (albino) 以外に, 色々のcoat color を持つ congenic $l p r$ マウスが出回ることが予想される。

一方, 後者む Murphyにより C57BL/6J と SB/Le との間の recombinant マウスとして inbred 化され， 自己免疫病を自然発症するが, 症状は雄においてはるか に重く, 多くの $\mathrm{F}_{1}$ の観察から BXSB 由来の $\mathrm{Y}$ chromosomeの存在が病状発現を大きく左右していることが分 った。そのような functional 遺伝子が Y chromosome に存在するとなると H-Y に次いでの発見となる。

c) Hairless mutation

ヌードマウスに批る athymia と hairlessness と は別の遺伝子によるものかどらか一時期問題になった が，現在異る遺伝子が関与しているといら証拠はない。 一つの遺伝子の pleiotropic 作用と考えて批いてよい。 この場合, 二つの異る遺伝子か関与していることを証明
するには正常に毛があって胸腺の無いマウスを示すしか ない。毛が無くて胸腺のある（通常発育不全である） mutant マウスは数多く知られて打り，特に hairless mutation はしばしば起り（最近, SJL/J に見つかり， この SJL/J-hr/hr マウスでは natural killer cell activity の低下が認められ, 白血病発生との関係にお いて研究が行われている), ヌードマウスの colony 内 にも起ることが予想されている。注意を要する。通常, 発毛障害のある mutant マウスは同時に免疫機能の障害 を伴っており，両者の因果関係は残された大きなトピッ クである。

\section{d) $\mathrm{C} 57 \mathrm{BL} / 6 \mathrm{~J}-b g^{J} / b g^{J}$}

ヒトの Chediak-Higashi syndrome のモデルとさ れる beige マウスは，2 年前に natural killer (NK) cell activity が低下していることが Nature 誌に載 り，より多くの免疫学者の注目を浴びることとなった。 しかし，少くともマウスに执いては， NK cell も T cell 同粎ほとんどの primary tumor の発生に対して 無力であろらことは想像に難くない。即ち, beige マウ スを長期間観察して自然発生腫瘍を比べても, コントロ ールマウスとの間に差が出ることは期待できない。出る とすれば, 系統によって lymphoreticular tumor ぐ らいのものであろら。70年代の immune surveillance に関する大論争を通じて我々が学んだことは，ある正常 動物を観察してある腫瘍の 発生が見られないとき， T cell, NK cell, Macrophage 等を主体とする central タイプの immunological surveillance system が存 在していて発生してくる腫瘍の芽を摘み取っているから ではなく，生理的な細胞の代謝回転の条件下では，腫瘍 の芽自体が多分 local なあえていらなら biological surveillance or anatomical system のため出現, 存 続できないといらことである。特に上皮性腫瘍を考える 場合, 自律性を有する腫瘍細胞の出現にはいくつもの step を必要とし, 遺伝的に, ageing により，あるい は発癌物質, 癌ウイルス, 前癌病変などでその臟器を特 徵づけている主要細胞が変性消失し, 局所的な cellular balance がくずされ，それを補らべく分裂能を持った reserve 細胞からの再生, 分化のくり返しのなかでよう 未分化な細胞がよう生存し易い状態が続いたとき，初め てある確率で出現してくるもので，その観察にはマウス の 2 年の寿命は充分だとは言えない。その点, 分裂能を 有したまま free cell として体内のどこにでも移動でき るリンパ球系の細胞は例外的な存在であり，ある意味で 転移能を持つ癌細胞を思わせる。即ち，三方から tight 
junction や basement membrane で囲ま利離, 死 滅へのエスカレーターに乗っている胃腸上皮細胞などと 違って，すでに体内に存在する free cellは，正常な局 所の regulation (microenviron ment) が乱れた時, 他の体細胞より少ないstep で腫場化できるのではなか ろらか。免疫不全に lymphoreticular tumor が圧倒的 に多く合併する理由は依然分っていない。 beige gene は Murphyによりいくつかの inbred strain に導入 されており，予備的データでは正常コントロールマウス との間に自然発生腫瘍の差は認められていない。

e) $\mathrm{C} 57 \mathrm{BL} / 10 \mathrm{~J}$

C57BL/10J マウスの雄は小さな睪丸を有しており， 組織学的には萎縮した精細管が正常な精細管と隣り合わ せに多数見られる。 genetic lesion と考えられている が, 詳しくは調べられていない。C57BL/10SnJ の雄に もやや軽いが同様の萎縮像がみられる。しかし，その congenic strain の5ち B10.A にはほとんどみられ ないが，そのある recombinant にはまたみられるとい らぐあいに興味ある問題を含んでおり，今後の研究が期 待される。

f) $\mathrm{SWR} / \mathrm{J}$

Swiss マウスから inbred 化された SWR/J 系マウ スは xenotropic virusを自然発現することは極めて稀 で, その virus を大量に自然発現し, SLE 様の自己 免疫病を発症する NZB strain と好対照をなすと考兄 られている。しかし, 今回の私達の研究で, この strain は post-thymectomy autoimmune diseases に対し ては高感受性であることが明らかとなった。即ち, 全身 性自己免疫疾患と異り, 少くともマウスの臟器局在性自 己免疫疾患においては endogeneous virus の役割はあ まり重要でないと考えられる。

最近, SWR/J の research colony の中で granulosa cell tumor を生後数ケ月で自然発生するマウスが 見つかった。遺伝的要因が重要と考えられ, 頻度を上げ るべくW. G. Beamer によって selection が行われ つつある。ヒトでも最近, juvenile granulosa cell tumor として新しいカテゴリーの卵巣腫瘍を区別しよ らといら動きがあり (Scully), 将来そのモデルになる ことも考えられる。

g) Recombinant inbred strains

1971年, D. W. Bailey により初めて報告された一組 （7 系統）の recombinant inbred (RI) strains は, 従来 mutant マウスの出現を待ってその gene の mappingを行っていたのと違い，既知の遺伝子座との lin- kage を利用して積極的に未定の遺伝子座を決定してゆ くことを可能にした。日本ではまだ活用している人がい ないと思われるので簡単に紹介すると，例えば私の実験 系で,マウスにおける post-thymectomy autoimmune gastritis の発生は, 特定の $\mathrm{H}-2$ haplotype との間に 相関を示さず，むしろある minor histocompatibility locus との間に linkage が示唆された（詳しくは, Kojima and Prehn:Genetic susceptibility to post-thymectomy autoimmune diseases in mice ; Immunogenetics, in press)。即ち, gastritis に対 する susceptibility gene を想定した場合， RI strains を使えば特定の $\mathrm{H}-2$ タイプと associate しないことが 分ると同時に, 既知の遺伝子との linkage パターンか らどの chromosome のどのあたりに存在しらるかの推 定が可能になる。同じよらに，B. A. Taylor の開発し た SWR/J と C57L/J 間の RI strains (SWXL, 7 系統）は, SWR/J が post-thymectomy autoimmune orchitis 及び post-vasectomy testicular autoimmunity の両者に対して susceptible strain であり，C57 $\mathrm{L} / \mathrm{J}$ が resistant strain であることが分ったので,これ を使ってそれぞれの病変に対する感受性遺伝子の chromosome 上の局在が推定可能かもしれない。今後我が 国でも大いに活用すべき資材である。

3）エピソード

昨今我が国ではラットに批るる韓国型出血熱の污染が 社会問題になっているが, 私の留学中アメリカでも一つ の騒ぎがあった。NIHの building 10 から発生したマウ スの ectromelia の感染で, 共同研究者等へのマウスの 移動により二次污染地が出るに及んで，Jax Labは厳 戒体制をとった。長期にわたって郵便物はガス滅菌さ れ，NIH 八の訪問などは見合わせるょう勧告が出た。 もともと, 外から Jax Lab 内へのマウス, 血清などの 生物学的資料の持ち込みは, その種の研究を犠牲にして までも厳しく規制されており，有名な10日間の quarantine 制度（他所のマウスやそれに準ずるものに触れた者 は, visitor でも, staff でも10日間研究棟に立入るこ とができない規則）の効果もあってか幸い何事もなく終 った。一方, Jax Lab の research colony 内の一部 長期生存マウスに見つかった pinworm の場合は，すべ ての研究者のマウスが対象となり, 投薬と同時にすべて の空調ダクトの交換といら大がかりな対策がとられた。 一部の mutant マウスが影響を受け死亡, 予定の研究 が進まず不満も聞かれた。共通の部屋を使い複数の研究 者が実験動物を維持する場合の污染防止のむずかしさを 
考えさせられた。研究の交流が盛んになり，動物を含む 資料の移動，交換が増えるとこの種のトラブルは必然的 に多くなる。研究者レベル，施設レベルで各様の自衛対 策を考えておくべきであろう。

Jax Lab の図書室はよく揃っていて便利である。日 本の雑誌では Gann と実験動物が一般雑誌棚に飾られ る。それ以外にも各医科大学から Medical Journal \& のが驚くほど送られてきて拈り，書庫の隅に製本もされ ず捨てるわけにもゆかずホコリをかぶって積まれてい る。便利に思ったのは, 雑誌の不備を補らべく論文 reprintのコレクションが別にあることである。誰かが Lab に無い論文の reprint を請求すれば，それは最釉的に整 理されてコレクションに残される。Staats 女史も積極 的に関係文献のコレクションに努めている。ある時, 当 時留学中の金子氏と私に, 元所長夫人で scientist の Margaret C. Green が日本遺伝学雑誌に載っている織 田銑一氏のマウスの microphthalmia mutant に関す る日本語の学会抄録のコピーを持参して訳してくれとい う。かくしてワイン一本と引き換えの我々の拙い英訳文 は reprint 棚の中に日本語のコピーといっしょに納めら れている。日本語でも，抄録でもよいから発表しておく ことが何よりも肝要だと教えられた次第である。

Jax Lab は Department 制をとっていないため個 々の staff scientist の独立性は高い。各研究者は原則 として一人の technician を研究所から保証されるだけ で，それ以外は自らのかせぐ研究費で賄わなければなら ない。従って，おのずと小規模で他との competitionを 気にせずに済む独創的な研究に的をしぼることになる。 そのため, original studyを保証するマウスの開発に は研究所，研究者とも絶えまない努力を払っている。さ らに，staff 同志がお互いの手技, 分野を寄せ合って高 いレベルでの共同研究をめざしている。同時に，おのず と研究テーマにより, あるいは有力な senior scientist を中心にグループができ，いくつかのセミナーが定期的 に開かれ, 若い人達の自由な参加が歓迎される。私も留 学して間もなく, Prehn の Tumor Immunology グル ープのセミナーを担当した時，始をる前にどこかで見た ことのある小柄でやせ型の老人が近寄ってきて「Snell です」と手を差し出されて恐縮したことを覚えている。 研究所全体のセミナーは少くとも私の滞在中は金曜日の 午後と決っており，そのための予算が外からとられ内外 の演者が選ばれる。少くとも週一回, 研究所の staff, retire した名誉 staff などが顔を揃えるいい機会で， セミナー前に coffee と cooky, 終ってから wine と cheese を手に語り，“Have a nice weekend!”となる のである。

4） Jax マウスの活かし方

研究者は誰しも, 自らの研究成果を世界に知らしめ, その領域の他の研究者に impact を与え, 追試, 確認 あるいは反論される過程で, science における貢献をし たいといら真摰な願いを有している。その研究が重要で あると自負すればな怙さらである。国際語としての英語 を用いて外国の学者と communicate するよ5に, 日 本で初めてみつけたマウスにおける現象を，外国の研究 者に最終的に納得させるためには，国際的に信頼でき， 誰もが入手できる（追試できる）スタンダードのマウス を用いて同様の結果が得られることを一度は示す必要が ある。かくして，信頼できる実験動物の供給体制を持た ない日本の現状では，それに代るものを外に求めざるを 得ない。その点に関し触れておきたいのは, 日本の業者 が Jax Lab との正式な契約なしにどこから Jax マウ スを入手し，繁殖させて Jax マウスとして供給するこ とで, これはモラルの点からも次に述べる観点からも充 分慎重でありたい。即ち，由来は Jax マウスであって も, 遺伝学的 check システムを持たない所で 8 代以上 sib mating を続けておれば, 小さな colony の場合 subline 化することを常に念頭におかねばならず，それ をそのまま意に介せず， strain の末尾は Jのまま論文 に書いて済ますことは，研究成果の比較を混乱させる原 因にもなりかねない。各研究者が Jax Lab より non一 pedigreed breeding pair を購入して増やし，自分の 研究に用いることは結構なことだが，研究用に入手した マウスは増やすにしてもある期間内に使い切ってしまら 心構えが大切で, 使らあてもないのにコレクションとし て non-pedigreed マウスを集めて維持するのは色々な 点から賢明でない。従って，Jax Lab が果してきた歴 史的役割に敬意を表するなら，それと同じようなものを 日本に作り維持することには非現実性とムダとを感じ る。むしろ，Jax マウスを使用することで斉む研究は， そのマウスを購入することで解决すべきで，その意味で Jax Lab はアメリカのみならず世界の財産と考えるべ きだと思う。フランスの場合は，政府の肝入りで契約書 をとり交し，定期的に pedigreed マウスを導入して増 産し, 自国の研究者に Jax 由来マウスとして供給, 便 を図っているといら。我が国へも Jax マウスを導入し ようといら計画をいくつか耳にしたか，私か～Animal Resources $の$ Hans Heiniger (Assistant Director) に尋ねたところ，文書で契約することが必要で，新しい 
所長が決ったら，Lab としてはいつでも交涉にあたる とのこと,さらに, 望ましい形は, 個々の業者との契約 でなくフランスとの場合のように信頼できる政府レベル の承認の下で，一括した形でやりたいとのことであっ た。日本の inbred マウスの将来はどらするのか，高い レベルからの判断が待たれる。

一方, 特殊なマウスを少数必要とする研究は今後さら に增えることと思われる。必要な時には hesitate する ことなく Jax マウスを注文し，使いこなし，自らの研 究を国際レベルにのせてほしいと思う。日本の研究者は 概して英文 letter を書くことに抵抗を感じるもので, そのわずらわしさを少しでも軽減するため，Jax マウ スの注文書の Formを作ってみた。通常の注文なら letterなど添える必要はなく必要事項の及書き込めば済
むよらになっている。

5）最後に

Jan Klein の紹介文ではないが (A sentimental journey to Bar Harbor : Fifty years of the Jackson Laboratory, Immunogenetics $8: 3 \sim 11,1979$ ) 確かに Bar Harbor は遠くにありても想う町である。 読者の方々も一度は寄られることを扸めしたい。George D. Snell Biomedical Laboratory のモダンな 建物が迎えてくれ，中に入ればどこか片隅に，日本の scientists の有志より50周年に際して贈られた, 名古屋 の芸術家, 山内一生氏による朝日に映える富士の頂の絵 が飾られているのを見つけられるかもしれない。

(6 月20日)

Official Letter Head ${ }^{1}$

Dear Sir :

Date of order

Re Jax mice order.

Ship to $o^{2)} \quad$ Bill $t^{3)}$

Name : $\quad$ Name :

Address : $\quad$ Address :

Telephone :

Telex number :

Cable address :

\begin{tabular}{lllll}
\hline Type of mice4) & \multicolumn{2}{c}{ Number of mice } & & \multicolumn{2}{c}{ Specific request } \\
\cline { 2 - 3 } \cline { 5 - 6 } & Female Male Total & $\begin{array}{l}\text { Age of mice } \\
(\mathrm{wks})\end{array}$ & $\begin{array}{l}\text { Weight } \\
(\mathrm{gram})\end{array}$ & Others \\
\hline
\end{tabular}

Requested shipping date: ${ }^{5)}$

Partial shipments accepted, minimum number: ${ }^{6)}$

Purpose of the experiments : ${ }^{7}$

Signature

(Order Form の説明)

これは, Animal Resources の Dorcas Corrow に 扮願いして Jax マウスの注文時に必要な事項を挙げて もらい作成したものです。宛先は，

Animal Resources

The Jackson Laboratory

Bar Harbor, Maine 04609

U. S. A.

Jax mice の price list 及び Jax Mice Handbook
（2 ドル必要）の申し込みもこの宛名でよい。

通関手続きのことを考えると注文以後のことは信頼出 来る業者に頼まざるを得ない。実際の発送が決まると注 文者に電報が届く。予想より $2 \sim 3$ 日遅れて着くのが通 例である。届いたマウスの箱に添付してある commercial invoice は概算なので, あわててこの額を支払わ ないよう。正式の invoice は 4 週間位遅れて届くので 待っておればよい。もし事故でマウスが死んであるいは 注文と違らマウスが着いた場合, 情況（餌は食べていた 
か，死因など）を参考のため書いて手紙で連絡すると新 たに送ってくる。マウスを送り返してはならない。

生産が悪く分与が遅れそらな場合には, 最近, 日本人 で入手した研究者の住所を教えてもらい，その人に頼む のも賢い手であるが，何でも都合よくもらえるものでも ない。

1）自分の所属の Letter Head を印刷したタイプ用紙 を使うのが望ましい。

2）タイプで, 確実に届く研究室の住所を。

3）科研費の都合などで，注文者以外の人が代金を払ら 場合，その人の住所を正しく。

4）例えば price list に載っているように詳しく正し く。Animal Resourees で生産のマウスはすべて末 尾に J がつく(C57BL/6ByJ)。研究者個人の research colony のマウス (C57BL/6By) と区別されている。
前者は安定した SPF だが, 後者は研究者の立ち入り 具合で時に感染することがありらる（定期的に検査は されているが)。 Retired breeder を除いて, 10週 令以上のマウスの注文はできない。

5) as soon as possible, earliest date after July 1 , 1981など。注文者の要求した時期に間に合わない時は 連絡がくる。

6）大量のマウスを一度に申し込む場合など，とりあえ ず一部でも先に送ってほしい時の指定。

7）極めて簡単でよい。 cancer research etc. 但し, list に載ってはいないが特定の scientist がすでに有 していることがわかっている貴重なマウスを，人に先 んじて分与を願う場合は, 相手の研究と抵触しないこ とを説いた手紙を，その研究者に直接出すのが礼儀。 紹介状をつけるのも良い。

\section{॥}

Animal model for immune dysfunction associated with adenosine deaminase deficiency. by A. Tedde, M. E. Balis, S. Ikehara, R. Pahwa, R. A. Good, and P. P. Trotta. Proc. Natl. Acad. Sci. USA 77, 4899-4903 (1980).

$\mathrm{B}$ およびT細胞両者の 免疫不全モデルマウスが adenosine deaminase (ADase), の結合抑制剂である $2^{\prime}-$ deoxyconformycin (DCF) の連続腹腔内投与によっ て作成された。DCF 投与により，胸腺，脾葴およびリ ンパ節の ADase は 57〜100\%の範囲で抑制された。 この条件での免疫不全は (1) コンカナバリン A, フィト ヘモアグルチニン，大腸菌リポポリサッカライド等分裂 誘起剂に対するリンパ球の反応の著明な低下。（2）遅延 性過敏反応性の障害。（3）抗体産生の低下。（4）異系又 ウス間皮麿移植に扣ける 拒絶反応の著るしい遅延。（5） 著るしいリンパ球減少，等によって示された。組織学的 には, 胸腺, 脾臓, リンパ節でリンパ性変性を著明に認 めたが，骨髄，腎，肺，消化管および肝等では如何なる 変化もみなかった。また T細胞に対する DCF の細胞毒 性の事実は, 脾やリンパ節での Thy-1 陽性細胞数の減 少からも支指された。また DCFを $0.4 \mathrm{mg} / \mathrm{kg} / \mathrm{day} 5$ 日間投与で食欲減退および体重隇少がみられた。

以上の成績から, 本法によりヒトにおける遺伝性の重 症複合免疫不全症の生化学的な将来の研究に対して優れ たモデルを実験的に作成し得たものと考える。
Distribution of conduritol $B$ epoxide in the animal model for Gaucher's disease (Gaucher mouse), by M. C. Stephens, A. Bernatsky, H. Singh, J. N. Kaufer, and G...nter Legler. Biochem. et Biophys. Acta, 672, 29-32 (1981).

Gaucher 病というのはスフインゴリピドージスの一 種で常染色体性劣性遺伝の疾患である。若年性急性型と 成人型に分類されるが，前者では中枢神経障害を伴う。 後者は良性で各種の血液異常と脾㵴肥大が主徵である。 生化学的には glucosylceramide の組織濃度の上昇拉 よびこのものの加水分解に関与する $\beta$-glucosidase 活 性の低下が認められている。先に著者らはこの $\beta$-glucosidase の㧕制剂を研究している際 conduritol Bepoxide が極めて強い抑制作用のあることを知り，これ をマウスに連続投与することにより Gaucher 病類似の 症状をマウスに発症させることに成功した (Biochem, Biophys. Res, Comm, 67, 85-90, 1975)。即ち glucosylceramide の組織濃度が著るしく上昇し，脳，肝， 脾における $\beta$-glucosidase 活性を93\%に減少させ得た。 この報告はその後の第 2 報として出されたもので，抑 制剂 $\left[{ }^{3} \mathrm{H}\right]$ conduritol B epoxide 投与後の各藏器への 分布の時間的経過をしらべ，投与の量および方法につい て更に検討を加えたものである。epoxideは迅速にあら ゆる臟器に分布されるが血液-脳関門の関係から脳へは 僅かしか入らず，他臓器では $90 \%$ 抑制がみられるのに 
対して37\%しか活性が抑制されなかった。

Spontaneous gastric erosions and ulcerations in BB Wistar rats. by J. R. Wright Jr, A. J. Yates, H. M. Sharma, and P. Thibert Laboratory Animal Science 31 : 63-66, 1981

1977年カナダの Bio Breeding (BB) Laboratories で生産された wistar ラットコロニーに若年性インスリ ン久乏性 糖尿病が 見出された。この $\mathrm{BBW}$ ラットは outbred であり, $2 \sim 4$ ケ令での糖尿病の自然発症率は 30〜 55\%であり, 遺伝様式も不明であるが, 選拔近親交配 を続ければ発生率が上昇することが予想される。 BBW ラットの糖尿病症状として高血糖, 糖尿, ケトアシドー シス，インスリン久乏症, グルカゴン血症, 高脂血症な どが見られ，発症後インスリン治療を施さねば多尿によ り脱水症状を来たし急激に体重減少して $1 \sim 2$ 週で死亡 する。

糖尿病とは直接関係はないが, 広範囲にわたる変性, 炎症，腫瘍性の異常がともならことが多く，ここで報告 された胃病変もその1つである。 BBW ラットのうち糖 尿病になったラット 134 匹（インスリン投与して延命さ せ糖尿病持続)，糖尿病発症しない兄妹 31 匹之，正常の wistar 系30匹について剖検した結果，胃の糜爛又は胃 潰瘍が琶められたラットは糖尿病群で 43 匹（32\%)，非 糖尿病兄妹群で 3 匹 (10\%) あり, 対照の wistar 系で は 1 匹も居なかった。また糖尿病による自然死をした 102 匹の剖検からの胃病変頻度は高く $(39 \%)$, 延命に必要 なインスリン投与量も胃病変陽性ラットの方が高くなる 結果が得られた。

胃病変の原因は複雑であり, 糖尿病それ自身よりも, ストレスの影響が強いと考えられる。病変は multifocal で胃壁の肥厚した腺部に見られ，胃裮の底部に起ること が多く, 急性の特徴を示す。このラットではガストリン 值は測っていないが，ヒトのZollinger-Ellison症候群 のように multifocal な胃潰瘳とガストリン分泌過多と が結びついた例があるので興味が持たれる。ストレス性 の胃潰瘍を実験的に作製する試みは数多くなされてきた が, 胃の非腺部や粘膜にだけ片寄るなどの欠点が目立っ ていた。従ってこの BBwistar ラットはヒトの急性の 胃ストレス性胃潰瘍のすぐれた自然発症モデルとして有 用であろう。( $\mathrm{MN})$

Inherited primary hypothyroidism in mice. by W. G. Beamer, E. M. Eicher, L. J. Maltais and

\section{J. L. Southard Science 212 : 61-63 1981}

新たに Hypothyroidism を起すマウスが Jackson 研究所で得られた。劣性の突然変異遺伝子 $(h y t)$ によ るもので第12染色体で centromere から約 30 単位離れ た座位に位置することも明らかになった。 $h y t / h y t マ$ ウスは発育の遅延から同定できるが, 甲状腺の乾燥粉末 を飼料に加えれば成長が正常に近づき繁殖力も雌雄共に 回復してくることから甲状腺機能低下が疑われる。軽度 の費血と血清コレステロール值上昇も甲状腺機能減退を 示唆する現象であって, 血清 $\mathrm{T}_{4}$ 值も測定不能の低値を 示す。

形態的に甲状腺は萎縮し, 甲状腺胞状細胞は小さく少 なく，扁平で細胞質を殆ど含まない。甲状腺機能減退症 には成因的に 1)合成，分泌など甲状腺自身の機能が低 下している第一次的 hypothyroidism と，2)下垂体 TSH の不足又は異常による第 2 次的 hypothyroidism ( $\mathrm{dw} / \mathrm{dw}$ マウスはこの例), 更に 3) 視床下部性の第 3 次 的な異常が考えられるが, $h y t / h y t$ マウスでは血清 T $\mathrm{SH}$ レベルが正常の10倍以上高值であり，外因性 TSH 処置に甲状腺が反応を示さないため，このマウスは形態 的にも機能的にも第一義的な甲状腺機能減退症を示すモ デルであると考えられる。（M.N.)

Dificiency of low density lipoprotein receptors in liver and adrenal gland of the WHHL rabbit, an animal model of familial hypercholesterolemia. by T. Kita, M. S. Brown, Y. Watanabe, and J. L. Goldstein. Proc. Natl. Acad. Sci. USA, 78 (4), 2268-2272 (1981)

家族性高コレステロール血症の患者の線維芽細胞には コレステロールの分解異化に重要な役割りをもつ LDL レセプターが欠損しているが, 肝葴, 副腎の細胞にも欠 損しているかどらかは解明されていない。そこで家族性 高コレステロール血症の患者と同様に, 線維芽細胞に LDL レセプターが欠損し，高コレステロール血症が自 然発症している遺伝性高脂血ウサギ（WHHL）が用い られ, 肝葴, 副腎に拈ける LDL レセプターの有無が調 ベられた。

肝臟，副腎の培養細胞に ${ }^{125} \mathrm{I}-\mathrm{LDL}$ と EDTA を加 えると, EDTA によって ${ }^{125} \mathrm{I}-\mathrm{LDL}$ が細胞膜に結合す ることが抑制される EDTA sensitive site と, 全く 抑制されないEDTA resistant site があることが示 されている。前者は線維芽細胞に拈ける LDL レセプタ 一と同じ機能を示し, 後者は LDL レセプターとは異っ 
たものであった。マウス, ラット, ウサギ, イヌ等では

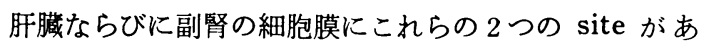
ることが知られているが，この実験で WHHL には EDTA sensitive site が欠損していること, すなわち
WHHL の肝臓, 副腎の細胞膜には LDL レセプターが 欠損していることが明らかにされ，家族性高コレステロ 一ル血症のモデルとして重要な動物であると報告されて いる。

（渡辺嘉雄）

แแแแแแแแแ Mouse News Letter 64 (Feb. 1981) より แแแแแแแแแ

Medical Research Council (D. Lovell 5) Laboratory Animal Center Carshalton, England

\section{beige locus の新らしい突然変異形質}

1974年に CBA/Ca Lac に見出された灰色毛色突然 変異形質に就いて C57BL/6J-bg ${ }^{J}$ 系の beige マウス と交配実験を行ったところ， $F_{1}$ (名4，ㅇ７）では全てが $\mathrm{CBA} / \mathrm{Ca} \mathrm{Lac}$ 型になったが, $\mathrm{F}_{2}$ 同志の交配では CBA/ $\mathrm{Ca}$ 型と, $\mathrm{C} 57 \mathrm{BL} / 6 \mathrm{~J}-\mathrm{bg}^{J}$ 型の体色に $38: 12$ の比で別 れ, agouti は現れなかった。この結果, 新らしい突然 変異形質は beige 形質の複対立形質であることが判った ので bg ${ }^{L a c}$ と名付けられた。

\section{脱毛の新らしい突然変異形質}

1978 年に DBA/I/Lac 系に見出された常染色体性劣 性遗伝を示す脱毛形質はVibrissae の数が少ないこと で, 出生直後から識別出来る。 juvenil hair は発現す るが, 3 週令になると脱毛が起り, 腹部下側にわずかに 残存するのみになる。体稫は正常同腹より小型で, やせ ている。大部分が乳離れ期前後に死亡する。nu, hr, と の allelism に就いては, test 中である。

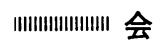

\section{公開シンポジゥム, 系統的血管病変の疾患モテル動物}

厚生省, 難病の疾患モデルに関する調査研究班 (班長 京極方久）は, 同じく厚生省系統的血管病変に関する調 查研究班 (班長福田芳郎) と合同で, 標記のシンポジウ 厶を昭和 56 年 8 月 2 日, 順天堂大学医学部有山記念講堂 で開催した。

I. 疾患モデル概説 (司会 : 安倍千之, 京極方久)

1. 疾患モデル研究の現況

東北大学 京極方久

2. 疾患モデルのあり方

愛知ガンセンター 西塚泰章
The Jackson Laboratory (Priscilla W Lane 5 ) 行動異常を示す新らしい突然変異形兵

1978 年に B6C3-a/a-myd/+系に見出された Twis ter (twt) は常染色体性劣性形質で, 尾を持ってつり上 げると，頭部をあたかも宙返りをするように上にあげ る。或るマウスは斜頸を示し, 又或るものは, ぐるぐる 回り行動を示すが, 全体的に聴覚は正常であり, 水泳は 出来ない。P遺伝子と $\mathrm{twt}$ 遺伝子との recombination test の結果から, 両遺伝子の間に $4.08 \%$ の距離が得ら れた。sh-1 との allelism は否定された。(Lane)

\section{眼疾㭧を発現する新らしい突然変異形質}

129/SV-ter 系に見出された劣性形質 Nuclear cataract (nuc) は， 3〜4 週令になると homozygote の 眼のレンズ中央部に白い部分が発現することで同定され る。両側性に発現し、レンズの表層部には異常がなく, 眼の大きさも正常である。複対立関係は無いが, Vacuolated lens 及び, blind sterile 形質に極めて類似して いるものと思われる (Varnum).

議

3. 矤患モデルの遺伝学的解析

II . 系統的動脈炎の疾患モデル

浜松医科大学 吉田孝人

(司会 : 柴田整一, 福田芳郎)

1. 自然発症モデル—SL/Ni と $\mathrm{MRL} / 1$ の場合 東北大学 川島正次/京極方久

2. 誘発モデル

i）血清病型，肉芽型動脈炎

東京医科大学 渡辺洋望/西川純子

ii）プレドニン投与実験における動脈病変 富山医科薬科大学 小泉富美朝/深瀬真之 
iii）リウマトイド因子と動脈炎

愛知医科大学 青木重久/生田耕司

（司会：安倍 達, 田中健蔵）

iv）カンディダ菌体抽出物投与による動脈炎作成実験 東邦大学 直江史郎／跡部俊彦／村田久雄 昭和大学 增田弘毅

v）モノクロタリン動脈炎

慶応大学 細田泰弘

3. 動脈炎と動脈硬化について一フィブリンと myointimal cell culture

九州大学 田中健蔵

4. 臨床応用

III. まとめ

順天堂大学 安倍千之/塩川優一

東北大学 京極方久

\section{Workshop "Identification of Animal Models of} Inborn Errors of Metabolism"

標記のワークショップが来たる10月19，20日に Bethesda MD の NIH で the Registrg of Compara- tive Pathology, AFIP と Universities Associated for Research and Education in Pathology, Inc. の共催のもとに関催される。目的はいらまでもなく動物 に打ける先天性代謝異常の臨床生化学的診断規準の評価 と決定である。話題としては特に次のものが予定されて いる。

Gene Structnre, Organization and Expression; Biochemical Variation and Comparative Gene Mapping; Hemoglobinopathies - Phenotype to Genotype : Detection : Epidemiologic and Family Studies; Recognition by Biochemical Methods; Animal Models of Lysosomal Storage Disease; Identification of Clotting Defects ; Use of Animal Models for Evaluation of Therapy for Genetic Disease; Animal Modesl of Collagen Disease; Mucopolysaccharidoses; Immunodeficiency Disease in Animals ; Histocompatibility, Disease and Aging ; Inherited Defects in Receptor Function ; $\mathrm{H}-\mathrm{Y}$ Antigen and Intersexuality in Animals.

献

Strobeck, Stephen M. Factor, Ashok Bhan, Michael Sole, C. C. Liew, Frederick Fein, and Edmund H. Sonnenblick ..................... 59

General Discussion.................................. 89

Part II. Muscular Dystrophy in the Mouse Embryology of Two Murine Muscle Diseases : Muscular Dystrophy and Muscular Dysgenesis. By Ann Platzer ................................. 94

Histometric and Electron Cytochemical Study of Muscle in the Dystrophic Mouse. By Betty Q. Banker, Neill S. Hirst, C. Susan Chester, and Randolph Y. Fok .115

Involvement of Peripheral and Central Nerves in Murine Dystrophy. By Walter G. Bradley and Evelyn Jaros 132

Physiologic Consequences of Neural Abnormalities in Murine Dystrophy. By Motoy Kuno

Muscular Dystrophy in the Mouse : Neuromuscular Transmission and the Concept of Functional Denervation. By J. B. Harris and R. R. Ribchester....................................152

Denervation Effects on Dystrophic and Normal Muscles and the Etiology of Dystrophy. By 
Richard J. Zeman and Alexander Sandow .......................171

Biochemical Studies in Dystrophic Mouse $\mathrm{Mu}$ scle. By K. P. Strickland, A. J. Hudson, and J. H. Thakar .................................. 187

Endocrine Pancreas in the Dystrophic Mouse. By Ingmar Lundquist, Rolf Håkanson, John B. Harris, Rolf Libelius, and Frank Sundler

General Discussion 206

Part III. Muscular Dystrophy in Birds

Major Physiologic and Histochemical Characteristics of Inherited Dystrophy of the Chicken. By Barry W. Wilson, William R. Randall, Gary T. Patterson, and Richard K. Entrikin . .224

Biochemical Studies of Dystrophy in the Young Chicken : Lysosomal and Sarcolemmal Enzymes. By Kenneth Owens $\ldots . \ldots \ldots \ldots \ldots \ldots \ldots \ldots \ldots 247$

Junctional and Extrajunctional Aspects of Inherited Muscular Dystrophy in Chickens : Development and Pharmacology. By J. E. Warnick, F. J. Lebeda, and E. X. Albuquerque

General Discussion...

Part IV. Inherited Diseases of Muscle in Large Animals

Neuromuscular Diseases of Domestic Animals : A Summary of Muscle Biopsies from 159 Cases. By George H. Cardinet, III and Terrell

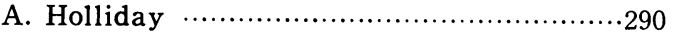

Myotonia in the Goat. By S. H. Bryant.........314

Malignant Hyperthermia in the Pig and the Role of Stress. By J. N. Lucke, G. M. Hall, and D. Lister .................................326

Part V. Therapeutic Trials in Dystrophic Laboratory Animals

Therapeutic Trials in Hamster Dystrophy. By G. Jasmin, B. Solymoss, and L. Proschek

Relationship between Myosin Structure and Muscle Degeneration. By A. Stracher, E. B. McGowan, L. Siemankowski, V. Molak, and

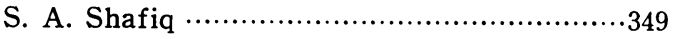

Mechanism of Action of Penicillamine in the Treatment of Avian Muscular Dystrophy. By Jane Harting Park, Edward J. Hill, TaHsu Chou, Virgil LeQuire, Robert Roelofs, and Charles R. Park ............................356

Penicillamine in the Therapy of Hereditary Muscular Dystrophy in Chickens. By John H. Milhorat and Ade T. Milhorat..............370
Use of Genetically Dystrophic Animals in Chemotherapy Trials and Application of Serotonin Antagonists as Antidystrophic Drugs. By Eric A. Barnard and Penelope J. Barnard 374

Pharmacologic Therapy of Dystrophy in Man and Animals. By Theodore L. Munsat........400 Part VI. Inherited Diseases of Muscle in Man and Animals : Comparative Aspects

Relevance of Genetic Animal Models of Muscular Dystrophy to Human Muscular Dystrophies. By J. R. Mendell, R. Higgins, Z. Sahenk, and E. Cosmos …..............................409

Involvement of the Nervous System in Muscular Dystrophies in Man. By V. Dubowitz

Morphologic Aspects of Muscle Breakdown and Lysosomal Activation. By M. J. Cullen, S. T. Appleyard, and L. Bindoff $\ldots \ldots \ldots \ldots \ldots \ldots \ldots \ldots \ldots, \ldots 40$

Muscle Breakdown and Lysosomal Activation (Biochemistry). By Carl M. Pearson and

Nirmal C. Kar.................................465

Muscle Regeneration in the Muscular Dystrophies. By J. R. Nichols and S. A. Shafiq........478

General Discussion...............................494 Part VII. Inherited Diseases of the Nervous System in Small Laboratory Animals : Their Relevance to the Study of NerveMuscle Interactions

Inherited Muscle and Nerve Diseases in Mice : A Tabulation with Commentary. By Richard L. Sidman, John S. Cowen, and Eva M. Eicher

Hereditary Disorders of Motor and Sensory Neurons in the Mouse. By L. W. Duchen ......................506

Axon-Schwann Cell Relationships in Neuropathies of Mutant Mice. By Albert J. Aguayo, Garth M. Bray, and Suzanne C. Perkins

General Discussion.................................532

Part VIII. New Perspectives in the Study of Muscle Disease

Thymic Changes in Muscular Dystrophy and Evidence for an Abnormality Related to Prostaglandin Synthesis or Action. By D. F. Horrobin, R. O. Morgan, R. A. Karmali, A. I. Ally, M. S. Manku, M. Karmazyn, and S.

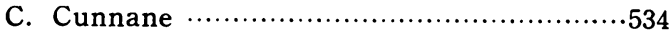

Tissue Culture Study of Murine Muscular Dysgenesis : Role of Spontaneous Action Potential Generation in the Regulation of Muscle Maturation. By Jeanne A. Powell, BethAnn 
Friedman, and Alda Cossi …...................550

Factors That Influence the Phenotypic Expression of Genetically Normal and Dystrophic Muscles. By Ethel Cosmos, Jane Butler, E. Paul Allard, and Jacob Mazliah.................571

Role of the Neural Tube in the Pathogenesis of Hereditary Muscular Dystrophy in the Chicken : Studies with Transplantation Chimeras. By Michel P. Rathbone and Patricia A. Stewart .........................................594

Parabiosis : An Appraisal of the Technique and Its Role in the Study of Muscle Diseases:in Animals. By W. B. Douglas, Jr, and A. Montgomery ...611

Mosaic Analysis of Dystrophic $\leftrightarrow$ Normal Chimeras: An Approach to Mapping the Site of Gene Expression. By Alan C. Peterson ……6.630

Phosphodiesters in Muscular Dystrophies. By Joseph M. Chalovich, C. Tyler Burt, Morris J. Danon, Thomas Glonek, and Michael Bárány 649

Adenylate Cyclase in Muscular Dystrophy. By Gideon A. Rodan, Sevgi B. Rodan, Donald G. Raible, Leslie S. Cutler, Mary Wacholtz, and Ramadan I. Sha'afi 670

Needs for New Animal Models of Human Disease

標記のワークショップが1980年 4 月 Bethesda, MD で開催され，その記録が Ameriean Journal of Pathology 12月号（1981）の付録として刊行されたが， 今 回その別刷が Universities Associated for Research and Edncation in Pathology, Inc., 9650 Rockville Pike, Bethesda, MD 20014 から 1 部 \$4,00 で入手で きることになった。

\section{筋ジストロフイー症動物の生産・開発に関する研究 昭和55年度研究報告}

厚生省神経疾患研究委託費の第 10 班として昭和 54 年度 から編成された標記の研究班（班長野村達次）では55年 度の研究報告書をこの程実験動物中央研究所より刊行し た。内容は次の通り。

I 、筋ジストロフィー症に関する文献(1979)…........ 1

野村 達次

II . 筋ジストロフィー症動物の生産と飼育管 理方法の研究

1. 筋ジストロフィー症動物の生産・供給………17 水谷 誠
江橋 節郎

斎藤 宗雄

2. 筋ジストロフィーニワトリ飼育用アイ

ソレータの開発

斎藤 宗雄

江崎孝三郎

III. 筋ジストロフィー症モデル動物の開発

1. ニホンウズラに护ける神経疾患研究用 系統の開発 27

若杉昇

近藤 恭司

2. 産業の場で見い出される異常ウズラの 調査. $\cdot 35$

疾患モデル動物の素材としての検討

伊藤 慎一

3. 筋ジストロフィー鵎 413 とコントロー ル鶏 412 の遺伝的背景の 差異と con. genic strain の必要性 $\cdot 41$ 水谷誠

4. ニワトリ筋ジストロフィー症の遺伝分

析 .55

一血清 pyruvate kinase 活性一

菊地 建機

5. ニワトリの筋ジストロフィー症に拉け

る機能障害の測定法 61

菊地 建機

6. ニワトリ筋ジストロフィー症に拈ける

骨の異常.... $\cdot 71$

菊地 建機

Genetic variants and strains of the laboratory mouse. by Margaret C, Green. Gustav Fischer Verlag, stuttgart, New York.

近日中に発刊されるこの書物はマウスの単一遺伝子の 変異体，染色体異常および純系等に関して網䍜した目録 をわれわれに提供している。いらまでもなくそれらは正 式な遺伝学命名法に基づき，また遺伝子地図や遺伝子相 互間の距離，あるいは染色体の異常部位等詳細な付図に よって説明されている。単一遺伝子の変異体の完全な目 録については1966年以来のものであり，且その時の 3 倍 の量に達している。また異常染色体個体のカタログにつ いては今回全く新らしくつくられたものである。それぞ れの研究領域に於て心要なマウスの変異体を探している 研究者にとっては, 非常に有益な書であるといえる。 